\title{
4
}

\section{Obesity and Systemic Inflammation: Insights into Epigenetic Mechanisms}

\author{
Perla Kaliman ${ }^{1}$ and Marcelina Párrizas ${ }^{2}$ \\ ${ }^{1}$ Systems Neuroscience Unit, IDIBAPS, \\ ${ }^{2}$ Endocrinology and Nutrition Unit, IDIBAPS, CIBERDEM, \\ Spain
}

\section{Introduction}

The global incidence and prevalence of obesity increase with every passing year, affecting both developed and developing countries. An appalling estimate of $75 \%$ of adults are projected to be overweight or obese in the United States by 2015 (Wang and Beydoun, 2007), thus raising serious concerns regarding the social and economic repercussions of obesity. The etiology of obesity is complex, with both genetic and environmental factors influencing its susceptibility and development (Campion et al., 2009; Russo et al., 2010). The detrimental effect of obesity on metabolic, cardiovascular and central nervous system dysfunction is well documented, as is its association with type 2 diabetes and cancer (Andersson et al., 2008; Bruce-Keller et al., 2009; Gallagher and LeRoith, 2010).

The continuing study of the adipose tissue over the past twenty years has transformed the perception that most investigators had of that organ. Despite being considered for decades no more than an uninteresting container for the storage of spare energy endowed with some useful mechanical and thermal insulating characteristics, the white adipose tissue (WAT) is actually an extremely dynamic endocrine organ that secretes a wide variety of hormones and cytokines, some of them in exclusivity, such as adiponectin (Zhang et al., 1994; Scherer et al., 1995; Kershaw and Flier, 2004; Trayhurn and Wood, 2004). Well over fifty adipokines have been described to date, with pleiotropic functions that highlight the involvement of the adipose tissue in the regulation of processes as varied as insulin sensitivity and glucose homeostasis, blood pressure, angiogenesis, fertility, immunity, neuroplasticity or inflammation (Trayhurn and Wood, 2004; Dietrich and Horvarth, 2009; Galic et al., 2010).

Obesity is defined by excess accumulation of white adipose mass, resulting from both an increase in adipocyte cell size (hypertrophy) and the development of new mature cells from undifferentiated precursors (hyperplasia) (Heine et al., 2000; Naaz et al., 2004). Serum levels of most adipokines increase with obesity, whereas others, notably adiponectin, decrease, upsetting the energetic balance of the organism (Trayhurn and Wood, 2004; Smith et al., 2006). Most importantly, the enlarged obese adipose tissue displays enhanced macrophage infiltration and behaves as a chronically inflamed organ (Weisberg et al., 2003; Xu et al., 2003).

The process of inflammation has evolved as a mechanism to repair a tissue after infection or physical damage has taken place. The acute inflammatory response is a controlled process initiated by tissue resident macrophages that after detecting infection or injury secrete a 
variety of inflammatory mediators that on the one hand attract leukocytes and platelets to the affected site, and on the other hand activate the endothelial cells, increasing their permeability to leukocytes (specifically neutrophils) while avoiding extravasation of erythrocytes (Medzhitov, 2008). The concluding stage of inflammation is resolution, mediated mainly by the tissue resident macrophages that secrete anti-inflammatory mediators to inhibit further recruitment of neutrophils while favoring that of monocytes that remove dead cells and participate in tissue repair and remodeling (Medzhitov, 2008). If resolution is not forthcoming, chronic inflammation ensues, ultimately resulting in tissue damage and metabolic demise of the organism.

Obesity is nowadays being accepted as a state of chronic low-grade inflammation (Xu et al., 2003; Weisberg et al., 2006). This inflammatory state impacts the function of many organs and tissues, from the adipose tissue itself to the endothelium, the central nervous system, the pancreas or the liver, and is being recognized as etiological of the aging process.

\section{The proinflammatory features of dysfunctional obese adipose tissue}

The white adipose tissue is constituted by a mixture of cell types, amongst which mature adipocytes represent the main fraction. Fat cell number is settled during adolescence or early adulthood in humans, but at least $10 \%$ of the total adipose mass is renewed every year (Spalding et al., 2008). In fact, recent reports indicate that $1-5 \%$ of total adipocytes may be replaced each day (Rigamonti et al., 2011). Mature adipocytes differentiate from progenitors, i.e. preadipocytes, which are present in the stromal-vascular fraction of the tissue that also contains, together with other minority cell types, a variable number of resident macrophages/monocytes (Rodeheffer et al., 2008). In physiological conditions, macrophages in WAT display an alternatively activated M2 phenotype, characterized by secretion of antiinflammatory cytokines such as IL-10 (Lumeng et al., 2007; Olefsky and Glass, 2010). However, the cellular composition of WAT is altered in obesity (Figure 1).

On the one hand, the number of committed preadipocytes capable of undergoing adipogenesis is reduced in obese individuals (Tchoukalova et al., 2004; Tchoukalova et al., 2007; Isakson et al., 2009). Conversely, the number of infiltrated macrophages is significantly increased in obesity. Macrophages may represent as much as a $30 \%$ of the total obese adipose tissue cell population, as compared to a $10 \%$ in lean tissue, in both human and rodent models (Weisberg et al., 2003; Xu et al., 2003). Moreover, macrophages infiltrating the obese adipose tissue switch to a classically activated M1 phenotype (Lumeng et al., 2007), resulting in enhanced proinflammatory cytokine production and systemic low-grade inflammation arising from the adipose tissue (Olefsky and Glass, 2010).

Obesity-associated inflammation has been linked to the development of major complications in acute pancreatitis (Evans et al., 2010), non-alcoholic fatty liver disease (Tilg, 2010), vascular inflammation and coronary artery disease (Andersson et al., 2008; Gomes et al., 2010), chronic obstructive pulmonary disease (Tkacova, 2010), risk of cerebral ischemia and brain injury (Denes et al., 2010) and atherosclerotic vascular disease and myocardial infarction (Ohman et al., 2009). Moreover, preclinical data suggest a link between obesity and cancer (Hursting et al., 2008; Roberts et al., 2010). In fact, it has been estimated that overweight and obesity account for approximately $20 \%$ of all cancer cases and scattered evidence indicates beneficial effects of weight loss on susceptibility and prognosis of some types of cancer (Wolin et al., 2010). This inflammatory state also underlies obesity-associated insulin resistance, and genetic inactivation of several inflammatory mediators or their 
receptors in macrophages improves insulin action and may prevent the development of diabetes in animal models (Arkan et al., 2005; Weisberg et al., 2006; Solinas et al., 2007).

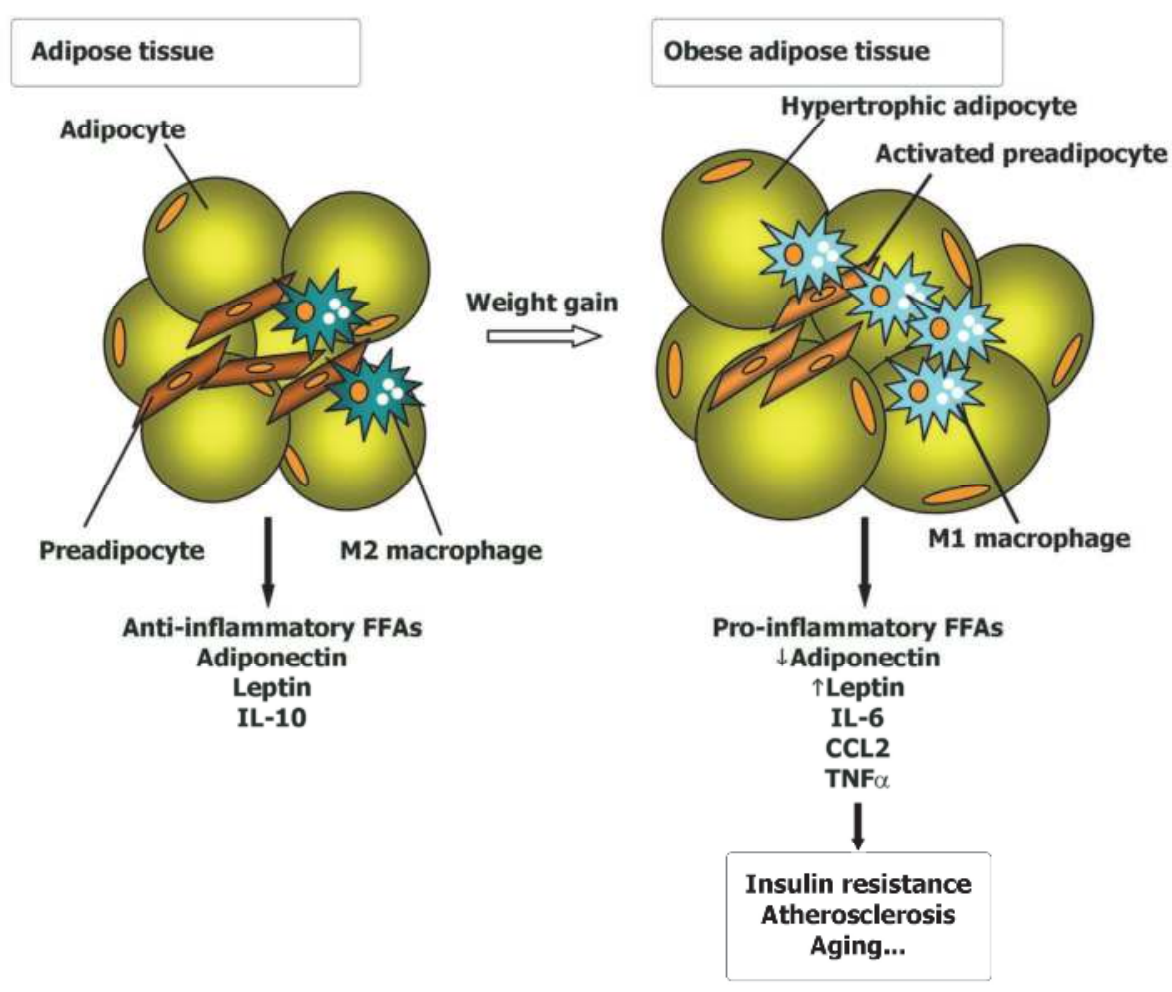

Fig. 1. The cellular composition of the adipose tissue is altered in obesity. Lean adipose tissue is composed of mature adipocytes and the stromal vascular cell fraction characterized by presence of adipose tissue stem cells, committed preadipocytes, endothelial cells and tissue resident macrophages with an alternatively activated M2 phenotype, which secrete anti-inflammatory IL-10. Adipocytes secrete leptin and adiponectin amongst other adipose tissue hormones. The obese adipose tissue is characterized by enlarged adipocytes that secrete increased levels of leptin giving rise to central and peripheral leptin resistance, and decreased levels of anti-inflammatory adiponectin. Macrophages infiltrate the obese adipose tissue in high numbers and polarize to a classically activated M1 phenotype, increasing secretion of proinflammatory cytokines such as TNF- $\alpha$ or IL- 6 . The inflammatory environment activates the preadipocytes that then acquire macrophage-like characteristics by expressing high levels of inflammatory cytokines and being unable to differentiate.

\section{Epigenetics of inflammation}

The concept of epigenetics refers to the study of cellular mechanisms that control somatically, and sometimes intergenerationally, inheritable gene expression states that are 
established in the absence of a change in the DNA sequence itself. Epigenetic mechanisms comprise an array of molecular modifications to both the DNA molecule itself and the histone proteins that associate with it, as well as the regulation by non-coding RNAs (Bernstein et al., 2007). Epigenetic processes drive the response of the cells to environmental cues by selectively activating or repressing transcription of subsets of genes and thus play a crucial role in regulating the transcriptional state and functionality of cells during development or in physiological and pathological conditions. Together with the genetic background (gene variants, polymorphisms) of an individual, the epigenetic modifications accumulated in the course of a lifetime of environmental influences dictate the susceptibility to and development of disease (Fraga et al., 2005; Poulsen et al., 2007). Remarkably, recent findings indicate that inflammation induces epigenetic alterations in tissues that then lay the basis for later disease manifestation (Backdahl et al., 2009).

Two of the most studied epigenetic mechanisms are DNA methylation and the posttranslational modifications of histones. DNA methylation is the process by which a cytosine residue present in a CpG dinucleotide is methylated by a DNA methyltransferase (Dnmt) enzyme (Gruenbaum et al., 1981). Methylation of CpGs located close to promoters usually results in gene silencing and plays a crucial role in developmental processes. Recent data have shown that DNA methylation is in some instances dependent on the pattern of histone post-translational modifications in the same gene region and vice versa (Fuks, 2005). Histone modifications create new binding sites for regulatory proteins, thus resulting in recruitment of specific activator/repressor complexes (Bartke et al., 2010; Oliver and Denu, 2011). Numerous reports have shown a clear link between the pattern of histone modifications in the chromatin of a given gene and its transcriptional status, and this has been considered indicative of the existence of a histone code, where the pattern of histone modifications at a gene region regulates the transcriptional outcome, as well as other DNA-based processes such as replication or DNA repair, either by modulating access to the DNA or by actively recruiting transcriptional regulators (Strahl and Allis, 2000; Turner, 2000; Jenuwein and Allis, 2001). In this regard, histone lysine acetylation is usually related to gene activation (Pokholok et al., 2005), whereas methylation results in different outcomes, depending on the modified residue (Lachner et al., 2001; Santos-Rosa et al., 2002; Talasz et al., 2005). Histone acetylation is the result of the interplay between histone acetyltransferases (HATs) and deacetylases (HDACs), whereas the enzymes responsible for histone methylation turnover are the histone methytransferases (HMTs) and demethylases (HDMs) (Couture and Trievel, 2006; Smith and Denu, 2009). Interestingly, many components of the basic transcriptional machinery and transcription factors can also undergo acetylation or metylation, which may in turn regulate their activity (Imhof et al., 1997; Egorova et al., 2010).

Non-coding RNAs (ncRNAs), on the other hand, are a large group of RNA molecules that are not translated into protein (Bernstein and Allis, 2005). Recent findings have unravelled a critical role for some of these RNA molecules, such as microRNAs (miRNAs), in the regulation of gene expression and genomic stability. miRNAs are 18-24 nucleotide long, single-stranded RNA molecules that suppress the expression of protein-coding mRNAs, either by directing translational repression or mRNA desestabilization (Bernstein and Allis, 2005).

DNA methylation, histone modifications and miRNAs play key roles in the differentiation of adipocytes and participate in the development of obesity (Esau et al., 2004; Fu et al., 2005; Musri et al., 2006; Noer et al., 2006; Yoo et al., 2006; Musri et al., 2007; Lee et al., 2008; Cho et 
al., 2009; Horii et al., 2009; Inagaki et al., 2009; Tang et al., 2009; Wakabayashi et al., 2009; Heneghan et al., 2010; Musri et al., 2010; Yang et al., 2010). Epigenetic processes are also implicated in the physiological and pathological inflammatory response (Bayarsaihan, 2011). Increased transcription of proinflammatory cytokine genes by master regulator NF- $\mathrm{KB}$ is associated with enhanced histone acetylation at their promoters (Yamamoto et al., 2003), as well as phosphorylation of Ser10 of histone H3 (H3Ser10) (Anest et al., 2003; Yamamoto et al., 2003). NF-אB regulatory kinase IKK- $\alpha$ can in fact phosphorylate H3Ser10 in vitro (Anest et al., 2003). On the other hand, expression of NF- $\kappa B$ itself in monocytes or neutrophils is regulated by several miRNAs, such as miR-9, whose expression is in its turn regulated by NF- $\kappa \mathrm{B}$, thus establishing a feedback loop that may control the degree of inflammation (Bazzoni et al., 2009). Dysregulation of any of these processes could generate an anomalous persistence of the inflammatory response in time, resulting in metabolic alterations and tissue damage.

\section{Impact of inflammation on the adipose tissue}

Several hypotheses have been proposed in an attempt to explain the role of the adipose tissue in the metabolic dysfunction associated with obesity. Thus, the altered pattern of adipokine secretion by the obese adipose tissue (Ukkola and Santaniemi, 2002; Tataranni and Ortega, 2005;), the inflammatory state associated with obesity (Cottam et al., 2004), or the inability of the adipose tissue to expand its mass in response to increased energy intake (Virtue and Vidal-Puig, 2010) have all been signaled as possible culprits. However, all these different hypotheses are not mutually exclusive.

Inflammation of the adipose tissue has been proposed as the critical element that distinguishes metabolically 'healthy' from 'unhealthy' obese subjects (Bluher, 2010), and a recent study has reported that increased inflammation in the adipose tissue precedes the development of obesity and insulin resistance in mice (Mori et al., 2010). Interestingly, preadipocytes display many functional and antigenic features in common with the monocyte/macrophage lineage and can actually be converted into macrophages given the adequate environment (Charriere et al., 2003). In fact, inflammatory cytokines such as tumor necrosis factor (TNF)- $\alpha$ and interleukin 6 (IL-6) block adipogenesis (Gustafson and Smith, 2006) and induce the expression and secretion of molecules that are not usually secreted by preadipocytes, such as IL-1 $\beta$, IL- 6 itself or the monocyte chemoattractant protein MCP-1 (Isakson et al., 2009). Therefore, inflammation has a double-hit effect on adipose tissue dysfunction by on the one hand decreasing adipogenesis and consequently cell turnover and expandability potential, and on the other increasing cytokine production thus establishing a self-sustaining cycle. Epigenetic mechanisms probably underlay this phenotype. In fact, overexpression of DNA methyltransferase Dnmt3a in mouse adipocytes results in enhanced expression of proinflammatory genes by the obese adipose tissue (Kamei et al., 2010). Obesity caused by high-fat diet increases DNA methylation at the leptin promoter in rat adipocytes, and this is associated with decreased circulating leptin levels (Milagro et al., 2009). Inflammatory cytokines such as TNF- $\alpha$ provoke wide transcriptomic changes in adipose tissue in vivo and in vitro (Ruan et al., 2002b; Isakson et al., 2009). In particular, TNF- $\alpha$ induces expression of the pseudokinase Tribbles 1 (Trb1) in mature adipocytes. Trb1 then binds to NF- $\mathrm{kB}$ target promoters and favors transcription of proinflammatory genes (Ostertag et al., 2010), thus creating a vicious circle. On the other 
hand, incubation of differentiated adipocytes in the presence of TNF- $\alpha$ suppresses expression of mature adipocyte genes, and reactivates the expression of those characteristic of the preadipocyte stage (Ruan et al., 2002a). Obesity produces the same effect, thus suggesting that the changes observed in obese adipose tissue are due to the proinflammatory environment (Xie et al., 2009). Moreover, obesity alters the pattern of adipose tissue-expressed miRNAs in the same fashion, by suppressing expression of mature adipocyte miRNAs, such as miR-103 or mir-143, while reactivating the expression of those highly expressed in preadipocytes, including miR-221 and miR-222, (Xie et al., 2009). Expression of miR-222 is also increased in 3T3-L1 adipocytes maintained under hyperglycemic conditions (Herrera et al., 2010) or in adipose tissue of mice treated with conjugated linoleic acid (Parra et al., 2010), indicating that it is involved in the pathophysiology of diabetes. Interestingly, a number of miRNAs play crucial functions in both the adipose tissue and the immune system. Thus, the miR-17 92 cluster accelerates adipogenesis in 3T3-L1 cells (Wang et al., 2008) and blocks monocytic differentiation of human CD34+ hematopoietic progenitor cells (Fontana et al., 2007), although this later effect is not seen in vivo in two different mouse models (Ventura et al., 2008; Xiao et al., 2008). Incidentally, however, no effect of miR-17 92 deficiency on the adipose tissue has been reported to date.

\section{Impact of inflammation on the endothelium}

Endothelial damage and associated increased cardiovascular risk is a fixture of obesity (Andersson et al., 2008). Endothelial cells incubated in the presence of preadipocytes treated with proinflammatory cytokines as compared with control preadipocytes express high levels of those cytokines themselves and display increased monocyte adhesion to them (Mack et al., 2009).

The regulatory role of epigenetic mechanisms in the pathogenesis of atherosclerosis and risk of coronary artery disease and stroke is increasingly being recognized (Wierda et al., 2010). Recent studies have shown that histone methylation is involved in establishing and maintaining the activated proinflammatory state of vascular smooth muscle cells (VSMC) in diabetic obese $d b / d b$ mice. Histone methyltransferase Suv39h1 is required to maintain high levels of repressive trimethylation of the lysine $\mathrm{K} 9$ of the histone $\mathrm{H} 3$ ( $\mathrm{H} 3 \mathrm{~K} 9 \mathrm{me} 3$ ) at the promoters of inflammatory genes in these cells (Villeneuve et al., 2008). In diabetic mice, expression of miR-125b increases in VSMCs and this results in decreased expression of its target Suv39h1 and thus decreased H3K9me3 methylation at the promoters of proinflammatory genes, coupled with increased gene expression (Villeneuve et al., 2010). Similarly, histone demethylase LSD1 is decreased in $d b / d b$ VSMCs, resulting in increased H3K4me2 levels and enhanced expression of inflammatory genes ccl2 and il6 (Reddy et al., 2008).

The key proinflammatory transcription factor NF- $\mathrm{\kappa B}$ is upregulated in endothelial cells as a response to hyperglycemia in vitro, and this is associated with binding of LSD1 and histone methyltransferase Set7 to its promoter and increased H3K4me1 methylation (Brasacchio et al., 2009). In its turn, NF-кB also associates with Set7 to stimulate transcription of its target genes in monocytes, and Set7 binding to proinflammatory promoters increases in macrophages from diabetic mice ( $\mathrm{Li}$ et al., 2008). Interestingly, one of the genes whose expression is increased by NF- $\mathrm{KB}$ and Set7 in macrophages treated with TNF- $\alpha$ is the 
histone demethylase JMJD3 (Li et al., 2008), thus suggesting a mechanism by which proinflammatory cytokines induce expression of chromatin-modifying enzymes in target cells to remodel chromatin and amplify the inflammatory response.

The expression of a number of miRNAs is also altered in endothelial cells incubated under inflammatory conditions (Dentelli et al., 2010). Expression of miR-222, for instance, is downregulated in endothelial cells exposed to inflammatory stimuli and its expression is negatively correlated with inflammation-mediated vascular remodeling through regulation of its target Signal Transducer and Activator of transcription 5A (STAT5A) (Dentelli et al., 2010). Treatment with Angiotensin II (Ang II) also has been shown to decrease the expression of miR-221/222 as well as miR-155 in human umbilical vein endothelial cells (HUVEC), and this decrease is associated with increased expression of their target Ets-1, a transcription factor that regulates the expression of adhesion molecules in endothelial cells (Zhu et al., 2011). Overexpression of miR-221/222 and miR-155 in HUVEC effectively decreased the adhesion of Jurkat T cells to Ang II-treated HUVEC (Zhu et al., 2011). Increased expression of adhesion molecules E-selectin and ICAM1 in endothelial cells treated with TNF- $\alpha$ is also mediated through changes in the expression of miRNAs such as miR-31 or miR-17-3p (Suarez et al., 2010).

\section{Obesity and aging}

Healthy aging and longevity are negatively influenced by inflammatory processes and metabolic alterations. The longevity phenotype seems to arise from a complex network of genetic, epigenetic and environmental factors interacting through still poorly characterized pathways. A negative relationship between adiposity and longevity has been recently proposed in an epidemiological study in healthy centenarians which revealed that low body fat mass, a nonatherogenic lipid profile and a better insulin sensitivity correlate with human longevity (Bluher, 2008). Moreover, telomere length, which is a marker of cellular senescence dependent of intricate epigenetic mechanisms, has recently been found to be decreased in human subjects with higher total and abdominal adiposity, further reinforcing the notion that obesity may accelerate the aging process (Lee et al., 2011).

Most of the longevity gene candidates described so far are related either to inflammatory functions, lipid and glucose metabolism or the stress response. Indeed, aging is characterized by chronic low-grade inflammation termed "inflammaging", in which a twoto fourfold increase in proinflammatory cytokines and acute phase protein production is observed (Jylhävä and Hurme, 2010). Notably, preadipocytes, which as mentioned are closely related to macrophages, dedifferentiate with aging and switch to a proinflammatory, senescent-like state (Tchkonia et al., 2010). However, a senescent-like state also develops in fat cells and preadipocytes from young obese subjects (Villaret et al., 2010).

Changes in DNA methylation levels and histone modification patterns have been detected throughout life although their effect on aging is only just beginning to be revealed (Siegmund et al., 2007; Dang et al., 2009; Greer et al., 2010; Siebold et al., 2010). Whether the age-dependent epigenetic drift is boosted by pathological metabolic situations such as obesity-related inflammation remains an unexplored territory. However, several observations point to a role for epigenetics in the regulation of lipid metabolism, inflammation and longevity. In organisms ranging from yeast to mammals, leanness and caloric restriction have been shown to increase longevity through the class III histone deacetylase sirtuin 1 (SIRT1), which acts in several cell processes by deacetylating both 
histones and transcription factors. A putative role for sirtuins as metabolic or oxidative sensors that respond to the cellular environment has been proposed (Frye et al, 1999). Interestingly, a potential protective role of SIRT1 against the metabolic consequences of chronic exposure to a high-fat diet has been recently described in a transgenic SIRT1 mouse model (Pfluger et al., 2008). Mice overexpressing SIRT1 and fed a high fat diet showed lower lipid-induced inflammation along with better glucose tolerance, and almost entire protection from hepatic steatosis compared with wild type controls. Such beneficial effects of SIRT1 correlated with increased expression of antioxidant proteins MnSOD and Nrf1 and reduced expression of proinflammatory cytokines, such as TNF- $\alpha$ and IL-6, probably by inhibiting NF-KB activity. Consistent with these observations, the AMPactivated protein kinase AMPK, acting through SIRT1 negatively regulates lipid-induced inflammation, indicating that this protein deacetylase may exert its anti-aging function at least in part through protection against obesity, inflammation, and insulin resistance (Yang et al., 2010). Interestingly, it has been shown that the natural compound resveratrol has anti-inflammatory effects in human adipose tissue through the SIRT1 pathway (Olholm et al., 2010) and several studies have described its capacity to extend lifespan in different species (i.e. S. cerevisae, C. elegans, and D. melanogaster) also through the sirtuin pathway, although other studies did not find an effect of resveratrol on lifespan. (Mouchiroud et al., 2010).

\section{Obesity and the central nervous system}

In a prospective cohort study conducted from 1997 to 2002 of 3075 subjects aged 70 to 79 years, an increased rate of cognitive decline was detected in those with high levels of serum markers of inflammation (Yaffe et al, 2004). Indeed, subclinical inflammation seems to be involved in the pathogenesis of cognitive impairment. Increased body mass and obesity have been related to cognitive decline, including decreased attentional performance, speed of processing and executive functions (Gunstad et al., 2007; Boeka et al, 2008; Fergenbaum et al, 2009). Moreover, midlife obesity is increasingly being described as a dementia risk factor in later life (Fitzpatrick et al, 2009). Reductions in brain volume in frontal, temporal, parietal, and occipital lobes, gray matter in temporal and frontal regions and white matter have been associated with obesity (Pannacciulli et al., 2006; Gunstad et al., 2008; Taki et al., 2008; Volkow et al., 2009; Ho et al., 2010; Stanek et al, 2011).

Neural oxidative stress, inflammation, and NF- $\mathrm{B}$ activation have been detected in cerebral cortex from rats fed a high fat diet (Zhang et al 2005), suggesting a link between diet-induced obesity and increased risk of dementia. This can be due, at least in part ,to triglyceride breakdown into free saturated fatty acids such as palmitic acid and lauric acid, which have been shown to modulate astrocytic and microglial signaling and to trigger inflammatory signals in macrophages (Patil et al, 2005; Laine et al, 2007). Another mechanism that seems to be involved in the peripheral modulation of CNS function is the impairment by triglycerides of leptin transport through the blood-brain barrier (Banks et al., 2004). Leptin is an afferent fatto-brain signal entering the brain via a saturable transport mechanism and acting at hypothalamic centers to regulate the feeding behavior. In addition to this well characterized hypothalamic function, leptin receptors are also widely expressed in other regions of the brain, including brain stem, cerebellum, amygdala and hippocampus (Fei et al., 1997; Elmquist et al., 1998) and a role for leptin in cognitive processes has been proposed (Harvey et al., 2005). For example, behavioral performance was improved in rats after intravenous administration of 
leptin (Oomura et al., 2006). Notably, leptin has been shown to modulate the inflammatory signaling in microglia (Pinteaux et al, 2007; Tang et al, 2007).

Recently, intergenerational effects of maternal obesity on the CNS have been reported in mouse models, sustained at least in part by epigenetic mechanisms. Indeed, maternal obesity induced by consumption of a high fat diet prior to and during pregnancy and lactation leads to metabolic alterations in the offspring together with behavioral and biochemical alterations within their CNS. For example, effects of prenatal and postnatal exposure to high fat diet (HFD) on the brain were studied by analyzing pups born to HFDinduced obese or control diet (CD) mothers (White et al, 2009). After weaning, male progeny was placed on a CD until 8 weeks old, and then fed either a HFD or a CD themselves. HFD progeny from HFD dams manifested a significantly increased cognitive decline associated with significant increases in 3-nitrotyrosine, iNOS, IL-6, and glial markers Iba-1 and GFAP. These data suggest that brain oxidative and inflammatory signaling is increased by HFD, and that maternal HFD-induced obesity might sensitize offspring. Other studies seem to support some of these observations. Diet-induced maternal obesity has recently been reported to impair hippocampal BDNF production and spatial cognitive function in young offspring, possibly due to metabolic and oxidative changes. (Tozuka et al, 2010). Similarly, in a recent report, rats were fed high-fat diets that created an obese phenotype or were maintained under a low-fat diet for 4 weeks prior to mating, throughout pregnancy and lactation (Bilbo and Tsang, 2010). At birth, pups from obese mothers showed increased serum leptin levels and microglial activation markers in the hippocampus. From weaning to adulthood, in response to a bacterial challenge (LPS), peripheral proinflammatory cytokines were significantly increased in offspring from obese mothers compared to controls. These changes were accompanied by higher anxiety levels in the HFD offspring. Although the cognitive susceptibility of the offspring from obese mothers to inflammatory insults was not evaluated, surprisingly rats born to obese mothers performed better in memory and spatial learning tasks than their low fat diet controls, suggesting that exposure to HFD during development may lead to different cognitive outcomes than during adulthood (Granholm et al., 2008; Murray et al., 2009). On the whole, these data suggest an obesity-induced early lifeprogramming that may be established by epigenetic mechanisms.

\section{Obesity and cancer}

The connection between obesity and cancer is extensively documented. Obesity has been reported as a cause of approximately $14 \%$ of cancer deaths in men and up to $20 \%$ of cancer deaths in women in a 25-year-prospective study of U.S. adults (Calle et al., 2003). In Europe, a review by the International Agency for Research on Cancer (IARC) in 2002 concluded that obesity was a cause of $39 \%$ of endometrial, $37 \%$ of esophageal, $25 \%$ of kidney, $11 \%$ of colon and $9 \%$ of postmenopausal breast cancer cases (International Agency for Research on Cancer, 2002). By contrast, being overweight or obese during childhood and adolescence appears to be protective against breast cancer (Ahlgren et al., 2004). Body weight has also been inversely associated with breast cancer in premenopausal women (Huang et al, 1997). Depending of the type of cancer, different mechanisms have been proposed that can be influenced by obesity for example the dysregulation of adipokines. Some of those that regulate the immune and the inflammatory response (i.e. leptin, TNF- $\alpha$, IL-6, serum amyloid A), seem to contribute to tumorigenesis, tumor progression and metastatic potential. Although evidence is still weak, inflammation is a mechanism gaining interest in 
the cancer field mainly because obesity-related inflammatory markers are increasingly associated with worse cancer prognosis (Pierce et al., 2009). Chronic inflammation has been linked to initiation and progression of different cancer types, including gastric (Farinati et al., 2008), hepatocellular (Fernandez-Irigoyen et al., 2008; Lukasiak et al., 2008), and colorectal (Wang \& DuBois, 2008) carcinoma. The tumor-associated stroma includes among other cell types adipocytes, inflammatory and immune cells and influences the development and progression of tumors through its interaction with transformed cells via soluble mediators, such as growth factors and cytokines (Mantovani et al., 2008; Ono et al., 2008).

Other means through which obesity-related chronic inflammation may influence cancer development is by altering the host antitumor immune response (Nave et al, 2008) and growth factor pathways. Indeed, recent data implicate IGF-I in the obesity-induced increase in tumor cell growth and support a critical role of inflammatory cytokines in the regulation of hepatic metastasis (Wu et al, 2010). Moreover, leptin, a proinflammatory adipokine increased in obesity, can induce eicosanoid production through a PI3K/mTOR-dependent pathway and activate resident macrophages to form adipose differentiation-related protein (ADRP)-enriched lipid droplets (Maya-Monteiro \& Bossa, 2008). Notably, human colon adenocarcinoma cell lines and colon cancer biopsies from patients have recently been shown to exhibit a drastic increase in ADRP and COX-2-enriched lipid bodies. The pathological implications of these changes are supported by data showing that inhibition of lipid droplet formation in cancer cells reduces PGE2 production and correlates with diminished cancer cell proliferation (Accioly et al., 2008).

Cells from the white adipose tissue can be recruited by tumors promoting cancer progression in mice. WAT cellular types engrafted in tumors include adipose stromal cells and adipose endothelial cells and their migration has been attributed to obesity-associated inflammation. (Zhang et al., 2009).

Although evidence for specific epigenetic mechanisms linking obesity-related chronic inflammation and cancer is currently lacking, several observations allow a link to be hypothesized. It has been proposed that aberrant epigenetic modifications can be induced by inflammation early in the process of carcinogenesis and that the accumulation of these modifications generates "an epigenetic field for cancerization" (Niwa and Ushijima, 2010). Alterations in cytokine and chemokine signaling seem to be involved in inflammationinduced aberrant DNA methylation. For example, IL-6 promotes the induction of significant global DNA hypomethylation as well as $\mathrm{CpG}$ promoter methylation changes in putative tumor suppressor genes such as CHFR, GATA5 and PAX6 in an in vitro model of inflammatory stress in squamous cell carcinoma (OSCC) cell lines (Gasche et al., 2011). Disturbances in the activity of DNA methyltransferases are increasingly related to the development of malignant phenotypes and it is interesting to note that the expression of the de novo methyltransferase Dnmt3a is increased in the adipose tissue and seems to contribute to obesity-related inflammation (Kamei et al., 2010).

Non-coding RNAs are also part of the cellular epigenetic machinery that regulates cell fate and functioning in response to environmental signals. Among them, miRNAs have been implicated in the control of a wide variety of biological processes ranging from proliferation and apoptosis to metabolism (Krol et al., 2010). Notably, several forms of human tumors present a robust upregulation of mir-221 and miR-222, two related miRNAs encoded in cluster on chromosome X (Garofalo et al., 2009; Rao et al., 2010; Pu et al, 2010; Zhang et al., 2010; Pineau et al., 2010; Galardi et al, 2011). Interestingly, miR-221 and miR-222 levels are downregulated during adipogenesis but increased in obese adipocytes. These changes have 
been attributed to the elevated TNF- $\alpha$ levels and the overall chronic inflammatory environment generated by the obese adipose tissue, as they were mimicked by treatment of differentiated 3T3-L1 adipocytes with TNF- $\alpha$ (Xie et al, 2009).

\section{Conclusions}

It is becoming increasingly evident that obesity is not only associated with metabolic alterations and decreased general wellbeing but it also represents a risk factor for the development of other chronic diseases such as cardiovascular disease, central nervous system dysfunction, cancer as well as accelerated aging (Figure 2).

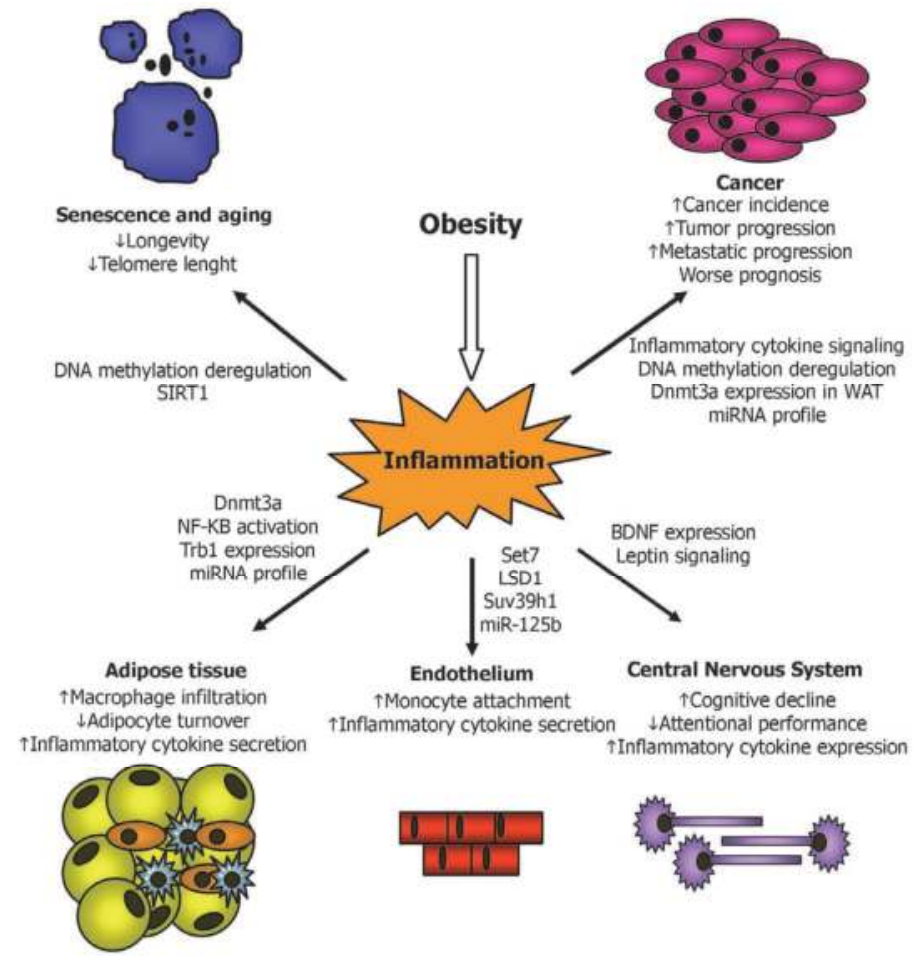

Fig. 2. Inflammation impacts tissue function and organismal aging. Inflammation causes increased macrophage infiltration and decreased adipocyte turnover in the adipose tissue, in part due to increased NF- $\kappa$ B activation, Trb1 expression and alteration of the miRNA profile. Overexpression of DNA methyltransferase Dnmt3a in adipose tissue also results in increased cytokine expression. In the endothelium inflammation increases expression of proiflammatory genes through the regulation of histone demethylases and methyltransferases LSD1, Set7 and Suv39h1, as well as miRNA miR-125b which targets Suv39h1. In the central nervous system, epigenetic effects of inflammation seem to be mediated by decreased BDNF expression and altered leptin signaling. Inflammation also impacts on cell senescence and organismal aging, through deregulation of the pattern of DNA methylation and histone deacetylase Sirt1, and in cancer initiation and progression, by growth-promoting cytokine signaling and deregulation of DNA methylation and the profile of miRNAs. 
Obesity is now recognized as an inflammatory disease. Inflammation impacts negatively the function of many organs and tissues through increased macrophage infiltration and decreased adipocyte turnover in the adipose tissue, in part due to increased NF-kB activation and Trb1 expression. Epigenetic mechanisms such as alteration of the miRNA profile and overexpression of DNA methyltransferase Dnmt3a in adipose tissue also result in increased cytokine expression. In the endothelium, inflammation increases expression of proiflammatory genes through the regulation of histone demethylases and methyltransferases LSD1, Set7 and Suv39h1, as well as miRNA miR-125b which targets Suv39h1. In the central nervous system, epigenetic effects of inflammation seem to be mediated by decreased BDNF expression and altered leptin signaling. Inflammation also impacts on cell senescence and organismal aging, through deregulation of the pattern of DNA methylation and histone deacetylase Sirt1. Inflammation may also affect cancer initiation and progression through growth-promoting cytokine signaling and deregulation of DNA methylation and the profile of miRNAs. The emerging picture of potential long lasting systemic alterations induced by obesity-related inflammation, some of which could be transmitted to subsequent generations, raises the urgent need to implement educative, preventive and therapeutic approaches to this serious health concern.

\section{Acknowledgments}

This work was supported by Ministerio de Ciencia e Innovación grants SAF2010-15050 to PK and BFU2009-09988/BMC to MP

\section{References}

Accioly, M.T.; Pacheco, P.; Maya-Monteiro, C.M.; Carrossini, N.; Robbs, B.K.; Oliveira, S.S.; Kaufmann C.; Morgado-Diaz, J.A.; Bozza, P.T., \& Viola, J.P. (2008) Lipid bodies are reservoirs of cyclooxygenase- 2 and sites of prostaglandin-E2 synthesis in colon cancer cells. Cancer Res., 68, 6, 1732-1740.

Ahlgren, M.; Melbye, M. ; Wohlfahrt, J., \& Sorensen, T.I. (2004) Growth patterns and the risk of breast cancer in women. N. Engl. J. Med. 351, 16, 1619-1626.

Andersson, C.X.; Gustafson, B.; Hammarstedt, A.; Hedjazifar, S., \& Smith, U. (2008) Inflamed adipose tissue, insulin resistance and vascular injury. Diabetes Metab. Res. Rev. 24, 595-603.

Anest, V.; Hanson, J.L.; Cogswell, P.C.; Steinbrecher, K.A.; Strahl, B.D., \& Baldwin, A.S. (2003) A nucleosomal function for IkappaB kinase-alpha in NF-kappaB-dependent gene expression. Nature. 423, 659-663.

Arkan, M.C.; Hevener, A.L.; Greten, F.R.; Maeda, S.; Li, Z.W.; Long, J.M.; Wynshaw-Boris, A.; Poli, G.; Olefsky, J., \& Karin, M. (2005) IKK-beta links inflammation to obesityinduced insulin resistance. Nat. Med. 11, 191-198.

Backdahl, L.; Bushell, A., \& Beck,S. (2009) Inflammatory signalling as mediator of epigenetic modulation in tissue-specific chronic inflammation. Int. J. Biochem. Cell Biol. 41, 176184.

Banks, W.A.; Coon, A.B.; Robinson, S.M.; Moinuddin, A.; Shultz, J.M.; Nakaoke, R., \& Morley, J.E. (2004) Triglycerides induce leptin resistance at the blood-brain barrier. Diabetes, 53, 5, 1253-1260. 
Bartke, T.; Vermeulen, M.; Xhemalce, B.; Robson, S.C.; Mann,M., \& Kouzarides, T. (2010) Nucleosome-interacting proteins regulated by DNA and histone methylation. Cell. $143,470-484$.

Bayarsaihan, D. (2011) Epigenetic mechanisms in inflammation. J. Dent. Res. 90, 9-17.

Bazzoni, F.; Rossato, M.; Fabbri, M.; Gaudiosi, D.; Mirolo, M.; Mori, L.; Tamassia, N.; Mantovani, A.; Cassatella, M.A., \& Locati,M. (2009) Induction and regulatory function of miR-9 in human monocytes and neutrophils exposed to proinflammatory signals. Proc. Natl. Acad. Sci. U.S.A. 106, 5282-5287.

Bernstein, B.E.; Meissner, A., \& Lander, E.S. (2007) The mammalian epigenome. Cell. 128, 669-681.

Bernstein, E. \& Allis, C.D. (2005) RNA meets chromatin. Genes Dev. 19, 1635-1655.

Bilbo, S.D., \& Tsang, V. (2010) Enduring consequences of maternal obesity for brain inflammation and behavior of offspring. FASEB J. 24, 6, 2104-2115.

Bluher, M. (2008) Fat tissue and long life. Obes. Facts., 1, 4, 176-82.

Bluher, M. (2010) The distinction of metabolically 'healthy' from 'unhealthy' obese individuals. Curr. Opin. Lipidol. 21, 38-43.

Boeka, A.G., \& Lokken, K.L. (2008) Neuropsychological performance of a clinical sample of extremely obese individuals. Arch. Clin. Neuropsychol., 23, 4, 467-474.

Brasacchio, D.; Okabe, J.; Tikellis, C.; Balcerczyk, A.; George, P.; Baker, E.K.; Calkin, A.C.; Brownlee, M.; Cooper, M.E., \& El-Osta, A. (2009) Hyperglycemia induces a dynamic cooperativity of histone methylase and demethylase enzymes associated with gene-activating epigenetic marks that coexist on the lysine tail. Diabetes. 58, 1229-1236.

Bruce-Keller, A.J.; Keller, J.N., \& Morrison, C.D. (2009) Obesity and vulnerability of the CNS. Biochim. Biophys. Acta. 1792, 395-400.

Calle, E.E.; Rodriguez, C.; Walker-Thurmond, K., \& Thun, M.J. (2003) Overweight, obesity, and mortality from cancer in a prospectively studied cohort of U.S. adults. N. Engl. J. Med. 348, 1625-1163.

Campion, J.; Milagro, F.I., \& Martinez, J.A. (2009) Individuality and epigenetics in obesity. Obes. Rev. 10, 383-92

Charriere, G.; Cousin, B.; Arnaud, E.; Andre, M.; Bacou, F.; Penicaud, L., \& Casteilla, L. (2003) Preadipocyte conversion to macrophage. Evidence of plasticity. J. Biol. Chem. $278,9850-9855$.

Cho, Y.W.; Hong, S.; Jin, Q.; Wang, L.; Lee, J.E.; Gavrilova, O., \& Ge, K. (2009) Histone methylation regulator PTIP is required for PPARgamma and C/EBPalpha expression and adipogenesis. Cell Metab. 10, 27-39.

Cottam, D.R.; Mattar, S.G.; Barinas-Mitchell, E.; Eid, G.; Kuller, L.; Kelley, D.E., \& Schauer, P.R. (2004) The chronic inflammatory hypothesis for the morbidity associated with morbid obesity: implications and effects of weight loss. Obes. Surg. 14, 589-600.

Couture, J.F. \& Trievel, R.C. (2006) Histone-modifying enzymes: encrypting an enigmatic epigenetic code. Curr. Opin. Struct. Biol. 16, 753-760.

Dang, W.; Steffen, K.K.; Perry, R.; Dorsey, J.A.; Jonson, F.B.; Shilatifard, A.; Kaeberstein, M.; Kennedy, B.K., \& Berger, S.L. (2009) Histone H4 Lysine 16 acetylation regulates cellular lifespan. Nature, 459, 7248, 802-807. Diabetes. 59, 11, 2755-2763. 
Denes, A.; Thornton, P.; Rothwell, N.J., \& Allan, S.M. (2010) Inflammation and brain injury: acute cerebral ischaemia, peripheral and central inflammation. Brain Behav. Immun. 24, 708-723.

Dentelli, P.; Rosso, A.; Orso, F.; Olgasi, C.; Taverna, D., \& Brizzi, M.F. (2010) microRNA-222 controls neovascularization by regulating signal transducer and activator of transcription 5A expression. Arterioscler. Thromb. Vasc. Biol. 30, 1562-1568.

Dietrich, M.O., \& Horvath, T.L. (2009) Feeding signals and brain circuitry. Eur. J. Neurosci. 30, 9, 1688-1696

Egorova, K.S.; Olenkina, O.M., \& Olenina,L.V. (2010) Lysine methylation of nonhistone proteins is a way to regulate their stability and function. Biochemistry (Mosc). 75, 535-548.

Elmquist, J.K.; Bjorbaek, C.; Ahima, R.S.; Flier, J.S., \& Saper, C.B. (1998) Distributions of leptin receptor mRNA isoforms in the rat brain. J. Comp. Neurol. 395, 4,535-547.

Esau, C.; Kang, X.; Peralta, E.; Hanson, E.; Marcusson, E.G.; Ravichandran, L.V.; Sun, Y.; Koo, S.; Perera, R.J.; Jain, R.; Dean, N.M.; Freier, S.M.; Bennett, C.F.; Lollo, B., \& Griffey, R. (2004) MicroRNA-143 regulates adipocyte differentiation. J. Biol. Chem. 279, 52361-52365.

Evans, A.C.; Papachristou, G.I., \& Whitcomb, D.C. (2010) Obesity and the risk of severe acute pancreatitis. Minerva Gastroenterol. Dietol. 56, 169-179.

Farinati, F.; Cardin, R.; Cassaro, M.; Bortolami, M.; Nitti, D.; Tieppo, C.; Zaninotto, G., \& Rugge, M. (2008) Helicobacter pylori, inflammation, oxidative damage and gastric cancer: a morphological, biological and molecular pathway. Eur. J. Cancer Prev., 17, 3, 195-200.

Fei, H.; Okano, H.J.; Li, C.; Lee, G.H.; Zhao, C.; Darnell, R., \& Friedman, J.M. (1997) Anatomic localization of alternatively spliced leptin receptors (Ob-R) in mouse brain and other tissues. Proc. Natl. Acad. Sci. USA., 94, 13, 7001-7005.

Fergenbaum, J.H.; Bruce, S.; Lou, W.; Hanley, A.J.; Greenwood, C., \& Young, T.K. (2009) Obesity and lowered cognitive performance in a Canadian First Nations population. Obesity (Silver Spring) 17, 10, 1957-1963.

Fernandez-Irigoyen J.; Santamaria, M.; Sanchez-Quiles, V.; Latasa, M.U.; Santamaría, E.; Muñoz, J.; Sánchez Del Pino, M.M.; Valero, M.L.; Prieto, J.; Avila, M.A., \& Corrales, F.J. (2008) Redox regulation of methylthioadenosine phosphorylase in liver cells: molecular mechanism and functional implications. Biochem. J., 411, 2, 457-465.

Fitzpatrick, A.L.; Kuller, L.H.; Lopez, O.L.; Diehr, P.; O'Meara, E.S.; Longstreth, W.T. Jr., \& Luchsinger, J.A. (2009) Midlife and late-life obesity and the risk of dementia: cardiovascular health study. Arch. Neurol. 66, 3, 336-342.

Fontana, L.; Pelosi, E.; Greco, P.; Racanicchi, S.; Testa, U.; Liuzzi, F.; Croce, C.M.; Brunetti, E.; Grignani, F., \& Peschle, C. (2007) MicroRNAs 17-5p-20a-106a control monocytopoiesis through AML1 targeting and M-CSF receptor upregulation. Nat. Cell Biol. 9, 775-787.

Fraga, M.F.; Ballestar, E.; Paz, M.F.; Ropero, S.; Setien, F.; Ballestar, M.L.; Heine-Suner, D.; Cigudosa, J.C.; Urioste, M.; Benitez, J.; Boix-Chornet, M.; Sanchez-Aguilera, A.; Ling, C.; Carlsson, E.; Poulsen, P.; Vaag, A.; Stephan, Z.; Spector, T.D.; Wu, Y.Z.; 
Plass,C., \& Esteller, M. (2005) Epigenetic differences arise during the lifetime of monozygotic twins. Proc. Natl. Acad. Sci. U.S.A. 102, 10604-10609.

Frye, R.A. (1999) Characterization of five human cDNAs with homology to the yeast SIR2 gene: Sir2-like proteins (sirtuins) metabolize NAD and may have protein ADPribosyltransferase activity. Biochem. Biophys. Res. Commun., 260, 1, 273-279.

Fu, M.; Rao, M.; Bouras, T.; Wang, C.; Wu, K.; Zhang, X.; Li, Z.; Yao, T.P., \& Pestell, R.G. (2005) Cyclin D1 inhibits peroxisome proliferator-activated receptor gammamediated adipogenesis through histone deacetylase recruitment. J. Biol. Chem. 280, 16934-16941.

Fuks, F. (2005) DNA methylation and histone modifications: teaming up to silence genes. Curr. Opin. Genet. Dev. 15, 490-495.

Galardi, S.; Mercatelli, N.; Farace, M.G., \& Ciafrè, S.A. (2011) NF-kB and c-Jun induce the expression of the oncogenic miR-221 and miR-222 in prostate carcinoma and glioblastoma cells. Nucleic. Acids. Res. (published online January 18 2011).

Galic, S.; Oakhill, J.S., \& Steinberg, G.R. (2010) Adipose tissue as an endocrine organ. Mol. Cell Endocrinol. 316, 129-139.

Gallagher, E.J. \& LeRoith, D. (2010) Insulin, insulin resistance, obesity, and cancer. Curr. Diab. Rep. 10, 93-100.

Garofalo, M.; Di Leva, G.; Romano, G.; Nuovo, G.; Suh, S.S.; Ngankeu, A.; Taccioli, C.; Pichiorri, F.; Alder, H.; Secchiero, P.; Gasparini, P.; Gonelli, A.; Costinean, S.; Acunzo, M.; Condorelli, G., \& Croce, CM. (2009) miR-221\&222 regulate TRAIL resistance and enhance tumorigenicity through PTEN and TIMP3 downregulation. Cancer Cell., 16, 6, 498-509.

Gasche, J.A.; Hoffmann, J.; Boland, C.R., \& Goel, A. (2011) Interleukin-6 promotes tumorigenesis by altering DNA methylation in oral cancer cells. Int. J. Cancer, (published online 7 January 2011).

Gomes, F.; Telo, D.F.; Souza, H.P.; Nicolau, J.C.; Halpern, A., \& Serrano, C.V., Jr. (2010) [Obesity and coronary artery disease: role of vascular inflammation]. Arq Bras. Cardiol. 94, 255-260.

Granholm AC.; Bimonte-Nelson HA.; Moore AB.; Nelson ME.; Freeman LR., \& Sambamurti K. (2008) Effects of a saturated fat and high cholesterol diet on memory and hippocampal morphology in the middle-aged rat. J. Alzheimers Dis., 14,2, 133-145.

Greer, E.L.; Maures, T.J.; Hauswirth, A.G.; Green, E.M.; Leeman, D.S.; Maro, G.S.; Han, S.; Banko, M.R.; Gozani, O., \& Brunet, A. (2010) Members of the H3K4 trimethylation complex regulate lifespan in a germline-dependent manner in C.elegans. Nature, 7304, 466, 383-387.

Gruenbaum, Y.; Stein, R.; Cedar, H., \& Razin,A. (1981) Methylation of CpG sequences in eukaryotic DNA. FEBS Lett. 124, 67-71.

Gunstad, J.; Paul, R.H.; Cohen, R.A.; Tate, D.F.; Spitznagel, M.B., \& Gordon, E. (2007) Elevated body mass index is associated with executive dysfunction in otherwise healthy adults. Compr. Psychiatry, 8, 1, 57-61.

Gunstad, J.; Paul, R.H.; Cohen, R.A.; Tate, D.F.; Spitznagel, M.B.; Grieve, S., \& Gordon, E. (2008) Relationship between body mass index and brain volume in healthy adults. Int. J. Neurosci., 118, 11, 1582-1593. 
Gustafson, B. \& Smith, U. (2006) Cytokines promote Wnt signaling and inflammation and impair the normal differentiation and lipid accumulation in 3T3-L1 preadipocytes. J. Biol. Chem. 281, 9507-9516.

Harvey, J.; Shanley, L.J.; O'Malley, D., \& Irving, A.J. (2005) Leptin: a potential cognitive enhancer? Biochem. Soc. Trans., 33, 5, 1029-1032.

Heine, P.A.; Taylor, J.A.; Iwamoto, G.A.; Lubahn, D.B., \& Cooke, P.S. (2000) Increased adipose tissue in male and female estrogen receptor-alpha knockout mice. Proc. Natl. Acad. Sci. U.S.A. 97, 12729-12734.

Heneghan, H.M.; Miller, N., \& Kerin, M.J. (2010) Role of microRNAs in obesity and the metabolic syndrome. Obes. Rev. 11, 354-361.

Herrera, B.M.; Lockstone, H.E.; Taylor, J.M.; Ria, M.; Barrett, A.; Collins, S.; Kaisaki, P.; Argoud, K.; Fernandez, C.; Travers, M.E.; Grew, J.P.; Randall, J.C.; Gloyn, A.L.; Gauguier, D.; McCarthy, M.I., \& Lindgren, C.M. (2010) Global microRNA expression profiles in insulin target tissues in a spontaneous rat model of type 2 diabetes. Diabetologia. 53, 1099-1109.

Ho, A.J.; Raji, C.A.; Becker, J.T.; Lopez, O.L.; Kuller, L.H.; Hua, X.; Lee, S.; Hibar, D.; Dinov, I.D.; Stein, J.L.; Jack, C.R. Jr.; Weiner, M.W.; Toga, A.W., \& Thompson, P.M. (2010) Obesity is linked with lower brain volume in 700 AD and MCI patients. Neurobiol. Aging, 31, 8, 1326-1339.

Horii, T.; Morita, S.; Kimura, M., \& Hatada, I. (2009) Epigenetic regulation of adipocyte differentiation by a Rho guanine nucleotide exchange factor, WGEF. PLoS. ONE. 4, e5809.

Huang, Z.; Hankinson, S.E.; Colditz, G.A.; Stampfer, M.J.; Hunter, D.J.; Manson, J.E.; Hennekens, C.H.; Rosner, B.; Speizer, F.E., \& Willett, W.C. (1997) Dual effects of weight and weight gain on breast cancer risk. JAMA 278, 17, 1407-1411.

Hursting, S.D.; Lashinger, L.M.; Wheatley, K.W.; Rogers, C.J.; Colbert, L.H.; Nunez, N.P., \& Perkins, S.N. (2008) Reducing the weight of cancer: mechanistic targets for breaking the obesity-carcinogenesis link. Best. Pract. Res. Clin. Endocrinol. Metab. 22, 659-669.

Imhof, A.; Yang, X.J.; Ogryzko, V.V.; Nakatani, Y.; Wolffe, A.P., \& Ge, H. (1997) Acetylation of general transcription factors by histone acetyltransferases. Curr. Biol. 7, 689-692.

Inagaki, T.; Tachibana, M.; Magoori, K.; Kudo, H.; Tanaka, T.; Okamura, M.; Naito, M.; Kodama, T.; Shinkai, Y., \& Sakai, J. (2009) Obesity and metabolic syndrome in histone demethylase JHDM2a-deficient mice. Genes Cells. 14, 991-1001.

International Agency for Research on Cancer (2002) Weight Control and Physical Activity, Volume 6. Lyon: International Agency for Research on Cancer, 1-315.

Isakson, P.; Hammarstedt, A.; Gustafson, B., \& Smith, U. (2009) Impaired preadipocyte differentiation in human abdominal obesity: role of Wnt, tumor necrosis factoralpha, and inflammation. Diabetes. 58, 1550-1557.

Jenuwein, T. \& Allis, C.D. (2001) Translating the histone code. Science 293, 1074-1080.

Jylhävä, J., \& Hurme, M. (2010) Gene variants as determinants of longevity: focus on the inflammatory factors. Pflugers Arch., 459, 2, 239-246.

Kamei Y.; Suganami T.; Ehara T.; Kanai S.; Hayashi K.; Yamamoto Y.; Miura S.; Ezaki O.; Okano M., \& Ogawa Y. (2010) Increased expression of DNA methyltransferase 3a in 
obese adipose tissue: studies with transgenic mice. Obesity (Silver Spring), 18, 2, 314321.

Kershaw, E.E. \& Flier, J.S. (2004). Adipose tissue as an endocrine organ. J. Clin. Endocrinol. Metab. 89, 2548-2556.

Krol, J.; Loedige, I., \& Filipowicz, W. (2010) The widespread regulation of microRNA biogenesis, function and decay. Nat. Rev. Genet., 11, 9, 597-610.

Lachner, M.; O'Carroll, D.; Rea, S.; Mechtler, K., \& Jenuwein, T. (2001) Methylation of histone H3 lysine 9 creates a binding site for HP1 proteins. Nature. 410, 116-120.

Laine PS.; Schwartz EA.; Wang Y.; Zhang WY.; Karnik SK.; Musi N.; Reaven PD. (2007) Palmitic acid induces IP-10 expression in human macrophages via NF-kappaB activation. Biochem. Biophys. Res. Commun., 358, 1, 150-155.

Lee, M.; Martin, H.; Firpo, M.A., \& Demerath, E.W. (2011) Inverse association between adiposity and telomere length: The Fels Longitudinal Study. Am. J. Hum. Biol., 23, 1, 100-106.

Lee, J.; Saha, P.K.; Yang, Q.H.; Lee, S.; Park, J.Y.; Suh, Y.; Lee, S.K.; Chan, L.; Roeder, R.G., \& Lee, J.W. (2008) Targeted inactivation of MLL3 histone H3-Lys-4 methyltransferase activity in the mouse reveals vital roles for MLL3 in adipogenesis. Proc. Natl. Acad. Sci. U.S.A. 105, 19229-19234.

Li, Y.; Reddy, M.A.; Miao, F.; Shanmugam, N.; Yee, J.K.; Hawkins, D.; Ren, B., \& Natarajan, R. (2008) Role of the histone H3 lysine 4 methyltransferase, SET7/9, in the regulation of NF-kappaB-dependent inflammatory genes. Relevance to diabetes and inflammation. J. Biol. Chem. 283, 26771-26781.

Lukasiak, S.; Schiller, C.; Oehlschlaeger, P.; Schmidtke, G.; Krause, P.; Legler, D.F.; Autschbach, F.; Schirmacher, P.; Breuhahn, K., \& Groettrup, M. (2008) Proinflammatory cytokines cause FAT10 upregulation in cancers of liver and colon. Oncogene 27, 46, 6068-6074.

Lumeng, C.N.; Bodzin, J.L., \& Saltiel, A.R. (2007) Obesity induces a phenotypic switch in adipose tissue macrophage polarization. J. Clin. Invest. 117, 175-184.

Mack, I.; BelAiba, R.S.; Djordjevic, T.; Gorlach, A.; Hauner, H., \& Bader, B.L. (2009) Functional analyses reveal the greater potency of preadipocytes compared with adipocytes as endothelial cell activator under normoxia, hypoxia, and TNFalpha exposure. Am. J. Physiol Endocrinol. Metab. 297, E735-E748.

Mantovani, A.; Allavena, P.; Sica, A., \& Balkwill, F. (2008) Cancer-related inflammation. Nature, 454, 7203,436-44.

Maya-Monteiro, C.M., \& Bozza, P.T. (2008) Leptin and mTOR: partners in metabolism and inflammation. Cell Cycle, 7, 12, 1713-1717.

Medzhitov,R. (2008) Origin and physiological roles of inflammation. Nature. 454, 428-435.

Milagro, F.I.; Campion, J.; Garcia-Diaz, D.F.; Goyenechea, E.; Paternain, L., \& Martinez, J.A. (2009) High fat diet-induced obesity modifies the methylation pattern of leptin promoter in rats. J. Physiol Biochem. 65, 1-9.

Mori, M.A.; Liu, M.; Bezy, O.; Almind, K.; Shapiro, H.; Kasif, S., \& Kahn, C.R. (2010) A Systems Biology Approach Identifies Inflammatory Abnormalities between Mouse Strains Prior to Development of Metabolic Disease. Diabetes. 59, 2960-71. 
Mouchiroud, L.; Molin, L.; Dallière, N., \& Solari, F. (2010) Life span extension by resveratrol, rapamycin, and metformin: The promise of dietary restriction mimetics for an healthy aging. Biofactors, 36, 5, 377-382.

Murray, A.J.; Knight, N.S.; Cochlin, L.E.; McAleese, S.; Deacon, R.M.; Rawlins, J.N., \& Clarke, K. (2009) Deterioration of physical performance and cognitive function in rats with short-term high-fat feeding. FASEB J. 23, 12, 4353-4360.

Musri, M.M.; Carmona, M.C.; Hanzu, F.A.; Kaliman, P.; Gomis, R., \& Parrizas, M. (2010) Histone demethylase LSD1 regulates adipogenesis. J. Biol. Chem. 285, 30034-30041.

Musri, M.M.; Corominola, H.; Casamitjana, R.; Gomis, R., \& Parrizas, M. (2006) Histone H3 lysine 4 dimethylation signals the transcriptional competence of the adiponectin promoter in preadipocytes. J. Biol. Chem. 281, 17180-17188.

Musri, M.M.; Gomis,R., \& Parrizas, M. (2007) Chromatin and chromatin-modifying proteins in adipogenesis. Biochem. Cell Biol. 85, 397-410.

Naaz, A.; Holsberger, D.R.; Iwamoto, G.A.; Nelson, A.; Kiyokawa, H., \& Cooke, P.S. (2004) Loss of cyclin-dependent kinase inhibitors produces adipocyte hyperplasia and obesity. FASEB J. 18, 1925-1927.

Nave, H.; Mueller, G.; Siegmund, B.; Jacobs, R.; Stroh, T.; Schueler, U.; Hopfe, M.; Behrendt, P.; Buchenauer, T.; Pabst, R., \& Brabant, G. (2008) Resistance of Janus kinase-2 dependent leptin signaling in natural killer (NK) cells: a novel mechanism of NK cell dysfunction in diet-induced obesity. Endocrinology, 149, 7, 3370-3378.

Niwa, T., \& Ushijima, T. (2010) Induction of epigenetic alterations by chronic inflammation and its significance on carcinogenesis. Adv. Genet., 71, 41-56

Noer, A.; Sorensen, A.L.; Boquest, A.C., \& Collas, P. (2006) Stable CpG hypomethylation of adipogenic promoters in freshly isolated, cultured, and differentiated mesenchymal stem cells from adipose tissue. Mol. Biol. Cell. 17, 3543-3556.

Ohman, M.K.; Wright, A.P.; Wickenheiser, K.J.; Luo,W., \& Eitzman, D.T. (2009) Visceral adipose tissue and atherosclerosis. Curr. Vasc. Pharmacol. 7, 169-179.

Olefsky, J.M. \& Glass, C.K. (2010) Macrophages, inflammation, and insulin resistance. Annu. Rev. Physiol. 72, 219-246.

Olholm, J.; Paulsen, S.K.; Cullberg, K.B.; Richelsen, B., \& Pedersen, S.B. (2010) Antiinflammatory effect of resveratrol on adipokine expression and secretion in human adipose tissue explants. Int. J. Obes. (Lond), 34, 10, 1546-1553.

Oliver, S.S. \& Denu, J.M. (2011) Dynamic interplay between histone H3 modifications and protein interpreters: emerging evidence for a "histone language". Chembiochem. 12, 299-307.

Ono M. (2008) Molecular links between tumor angiogenesis and inflammation: inflammatory stimuli of macrophages and cancer cells as targets for therapeutic strategy. Cancer Sci., 99, 8, 1501-1506.

Oomura, Y.; Hori, N.; Shiraishi, T.; Fukunaga, K.; Takeda, H.; Tsuji, M.; Matsumiya, T.; Ishibashi, M.; Aou, S.; Li, X.; Kohno, D.; Uramura, K.; Sougawa, H.; Yada, T.; Wayner, M., \& Sasak,i K. (2006) Leptin facilitates learning and memory performance and enhances hippocampal CA1 long-term potentiation and CaMK II phosphorylation in rats. Peptides, 27, 11, 2738-2749. 
Ostertag, A.; Jones, A.; Rose, A.J.; Liebert, M.; Kleinsorg, S.; Reimann, A.; Vegiopoulos, A.; Berriel, D.M.; Strzoda, D.; Yamamoto, M.; Satoh, T.; Akira, S., \& Herzig, S. (2010) Control of adipose tissue inflammation through TRB1. Diabetes. 59, 1991-2000.

Pannacciulli, N.; Del Parigi, A.; Chen, K.; Le, D.S.; Reiman, E.M., \& Tataranni, P.A. (2006) Brain abnormalities in human obesity: a voxel-based morphometric study. Neuroimage, 31, 4, 1419-1425.

Parra, P.; Serra, F., \& Palou, A. (2010) Expression of adipose microRNAs is sensitive to dietary conjugated linoleic acid treatment in mice. PLoS. ONE. 5, e13005.

Patil, S., \& Chan, C. (2005) Palmitic and stearic fatty acids induce Alzheimer-like hyperphosphorylation of tau in primary rat cortical neurons. Neurosci. Lett., 384, 3 , 288-293.

Pfluger, P.T.; Herranz, D.; Velasco-Miguel, S.; Serrano, M., \& Tschöp, M.H. (2008) SIRT1 protects against high-fat diet-induced metabolic damage. Proc. Natl. Acad. Sci. U.S.A. 105, 28, 9793-9798.

Pierce, B.L.; Ballard-Barbash, R.; Bernstein, L.; Baumgartner, R.N.; Neuhouser, M.L.; Wener, M.H.; Baumgartner, K.B.; Gilliland, F.D.; Sorensen, B.E.; McTiernan, A., \& Ulrich, C.M. (2009) Elevated biomarkers of inflammation are associated with reduced survival among breast cancer patients. J. Clin. Oncol., 27, 21, 3437-3444.

Pineau, P.; Volinia, S.; McJunkin, K.; Marchio, A.; Battiston, C.; Terris, B.; Mazzaferro, V.; Lowe, S.W.; Croce, C.M., \& Dejean, A. (2010) miR-221 overexpression contributes to liver tumorigenesis. Proc. Natl. Acad. Sc.i U. S. A. 107, 1, 264-269.

Pinteaux, E.; Inoue, W.; Schmidt, L.; Molina-Holgado, F.; Rothwell, N.J., \& Luheshi, G.N. (2007) Leptin induces interleukin-1beta release from rat microglial cells through a caspase 1 independent mechanism. J. Neurochem., 102, 3, 826-833.

Pokholok, D.K.; Harbison, C.T.; Levine, S.; Cole, M.; Hannett, N.M.; Lee, T.I.; Bell, G.W.; Walker, K.; Rolfe, P.A.; Herbolsheimer, E.; Zeitlinger, J.; Lewitter, F.; Gifford, D.K., \& Young, R.A. (2005) Genome-wide map of nucleosome acetylation and methylation in yeast. Cell. 122, 517-527.

Poulsen, P.; Esteller, M.; Vaag, A., \& Fraga, M.F. (2007) The epigenetic basis of twin discordance in age-related diseases. Pediatr. Res. 61, 38R-42R.

Pu XX.; Huang GL.; Guo HQ.; Guo CC.; Li H.; Ye S.; Ling S.; Jiang L.; Tian Y., \& Lin TY. (2010) Circulating miR-221 directly amplified from plasma is a potential diagnostic and prognostic marker of colorectal cancer and is correlated with p53 expression. J. Gastroenterol. Hepatol. 25, 10, 1674-80.

Rao, X.; Di Leva, G.; L,i M.; Fang, F.; Devlin, C.; Hartman-Frey, C.; Burow, ME.; Ivan, M.; Croce, C.M., \& Nephew, K.P. (2011) MicroRNA-221/222 confers breast cancer fulvestrant resistance by regulating multiple signaling pathways. Oncogene, 30, 9, 1082-1097.

Reddy, M.A.; Villeneuve, L.M.; Wang, M.; Lanting, L., \& Natarajan, R. (2008) Role of the lysine-specific demethylase 1 in the proinflammatory phenotype of vascular smooth muscle cells of diabetic mice. Circ. Res. 103, 615-623.

Rigamonti, A.; Brennand, K.; Lau, F., \& Cowan, C.A. (2011) Rapid cellular turnover in adipose tissue. PLoS. ONE. 6, e17637. 
Roberts, D.L.; Dive, C., \& Renehan, A.G. (2010) Biological mechanisms linking obesity and cancer risk: new perspectives. Annu. Rev. Med. 61, 301-316.

Rodeheffer, M.S.; Birsoy, K., \& Friedman, J.M. (2008) Identification of white adipocyte progenitor cells in vivo. Cell. 135, 240-249.

Ruan, H.; Hacohen, N.; Golub, T.R.; Van, P.L., \& Lodish, H.F. (2002a) Tumor necrosis factoralpha suppresses adipocyte-specific genes and activates expression of preadipocyte genes in 3T3-L1 adipocytes: nuclear factor-kappaB activation by TNF-alpha is obligatory. Diabetes. 51, 1319-1336.

Ruan, H.; Miles, P.D.; Ladd, C.M.; Ross, K.; Golub, T.R.; Olefsky, J.M., \& Lodish, H.F. (2002b) Profiling gene transcription in vivo reveals adipose tissue as an immediate target of tumor necrosis factor-alpha: implications for insulin resistance. Diabetes. 51, 3176-3188.

Russo, P.; Lauria, F., \& Siani, A. (2010) Heritability of body weight: Moving beyond genetics. Nutr. Metab Cardiovasc. Dis. 20, 691-7

Santos-Rosa, H.; Schneider, R.; Bannister, A.J.; Sherriff, J.; Bernstein, B.E.; Emre, N.C.; Schreiber, S.L.; Mellor, J., \& Kouzarides, T. (2002) Active genes are tri-methylated at K4 of histone H3. Nature 419, 407-411.

Scherer, P.E.; Williams, S.; Fogliano, M.; Baldini, G., \& Lodish, H.F. (1995) A novel serum protein similar to C1q, produced exclusively in adipocytes. J. Biol. Chem. 270, 2674626749.

Siebold, A.P.; Banerjee, R.; Tie, F.; Kiss, D.L.; Moskowitz, J., \& Harte, P.J. (2010) Polycomb Repressive Complex 2 and Trithorax modulate Drosophila longevity and stress resistance, Proc. Natl. Acad. Sci. U.S.A., 107, 1, 169-179.

Siegmund, K.D.; Connor, C.M.; Campan, M.; Long, T.I.; Weisenberger, D.J.; Biniszkiewicz, D.; Jaenisch, R.; Laird, P.W., \& Akbarian, S. (2007) DNA methylation in the human cerebral cortex is dynamically regulated throughout the life span and involves differentiated neurons. PLoS One, 2, e895.

Smith, B.C. \& Denu, J.M. (2009) Chemical mechanisms of histone lysine and arginine modifications. Biochim. Biophys. Acta. 1789, 45-57.

Smith, J.; Al Amri, M.; Dorairaj, P., \& Sniderman, A. (2006) The adipocyte life cycle hypothesis. Clin. Sci. (Lond). 110, 1-9.

Solinas, G.; Vilcu, C.; Neels, J.G.; Bandyopadhyay, G.K.; Luo, J.L.; Naugler, W.; Grivennikov, S.; Wynshaw-Boris, A.; Scadeng, M.; Olefsky, J.M., \& Karin, M. (2007) JNK1 in hematopoietically derived cells contributes to diet-induced inflammation and insulin resistance without affecting obesity. Cell Metab. 6, 386-397.

Spalding, K.L.; Arner, E.; Westermark, P.O.; Bernard, S.; Buchholz, B.A.; Bergmann, O.; Blomqvist, L.; Hoffstedt, J.; Naslund, E.; Britton, T.; Concha, H.; Hassan, M.; Ryden, M.; Frisen, J., \& Arner, P. (2008) Dynamics of fat cell turnover in humans. Nature. 453, 783-787.

Stanek, K.M.; Grieve, S.M.; Brickman, A.M.; Korgaonkar, M.S.; Paul, R.H.; Cohen, R.A., \& Gunstad, J.J. (2011) Obesity is associated with reduced white matter integrity in otherwise healthy adults. Obesity (Silver Spring), 19, 3, 500-504.

Strahl, B.D. \& Allis, C.D. (2000). The language of covalent histone modifications. Nature. 403, 41-45. 
Suarez, Y.; Wang, C.; Manes, T.D., \& Pober, J.S. (2010) Cutting edge: TNF-induced microRNAs regulate TNF-induced expression of E-selectin and intercellular adhesion molecule-1 on human endothelial cells: feedback control of inflammation. J. Immunol. 184, 21-25.

Taki, Y.; Kinomura, S.; Sato, K.; Inoue, K.; Goto, R.; Okada, K.; Uchida, S.; Kawashima, R., \& Fukuda, H. (2008) Relationship between body mass index and gray matter volume in 1,428 healthy individuals. Obesity (Silver Spring), 16, 1, 119-124.

Talasz, H.; Lindner, H.H.; Sarg, B., \& Helliger, W. (2005) Histone H4-lysine 20 monomethylation is increased in promoter and coding regions of active genes and correlates with hyperacetylation. J. Biol. Chem. 280, 38814-38822.

Tang, C.H.; Lu, D.Y.; Yang, R.S.; Tsai, H.Y.; Kao, M.C.; Fu, W.M., \& Chen, Y.F. (2007) Leptininduced IL-6 production is mediated by leptin receptor, insulin receptor substrate1, phosphatidylinositol 3-kinase, Akt, NFkappaB, and p300 pathway in microglia. J. Immunol. 179, 2,1292-302.

Tang, Y.F.; Zhang, Y.; Li, X.Y.; Li, C.; Tian, W., \& Liu, L. (2009) Expression of miR-31, miR$125 b-5 p$ and miR-326 in the Adipogenic Differentiation Process of Adipose-Derived Stem Cells. OMICS. 13, 331-336.

Tataranni, P.A. \& Ortega, E. (2005) A burning question: does an adipokine-induced activation of the immune system mediate the effect of overnutrition on type 2 diabetes? Diabetes. 54, 917-927.

Tchkonia, T.; Morbeck, D.E.; Von Zglinicki, T.;, Van Deursen, J.; Lustgarten, J.; Scrable, H.; Khosla, S.; Jensen, M.D., \& Kirkland, J.L.(2010) Fat tissue, aging, and cellular senescence. Aging Cell, 9, 5, 667-684.

Tchoukalova, Y.; Koutsari, C., \& Jensen, M. (2007) Committed subcutaneous preadipocytes are reduced in human obesity. Diabetologia. 50, 151-157.

Tchoukalova, Y.D.; Sarr, M.G., \& Jensen, M.D. (2004) Measuring committed preadipocytes in human adipose tissue from severely obese patients by using adipocyte fatty acid binding protein. Am. J. Physiol Regul. Integr. Comp Physiol. 287, R1132-R1140.

Tilg, H. (2010) The role of cytokines in non-alcoholic fatty liver disease. Dig. Dis. 28, 179-185.

Tkacova, R. (2010) Systemic inflammation in chronic obstructive pulmonary disease: may adipose tissue play a role? Review of the literature and future perspectives. Mediators. Inflamm. 585989.

Tozuka, Y.; Kumon, M.; Wada, E.; Onodera, M.; Mochizuki, H., \& Wada, K. (2010) Maternal obesity impairs hippocampal BDNF production and spatial learning performance in young mouse offspring. Neurochem. Int. 57, 3, 235-247.

Trayhurn, P. \& Wood, I.S. (2004) Adipokines: inflammation and the pleiotropic role of white adipose tissue. Br. J. Nutr. 92, 347-355.

Turner, B.M. (2000) Histone acetylation and an epigenetic code. Bioessays. 22, 836-845.

Ukkola, O. \& Santaniemi, M. (2002) Adiponectin: a link between excess adiposity and associated comorbidities? J. Mol. Med. 80, 696-702.

Ventura, A.; Young, A.G.; Winslow, M.M.; Lintault, L.; Meissner, A.; Erkeland, S.J.; Newman, J.; Bronson, R.T.; Crowley, D.; Stone, J.R.; Jaenisch, R.; Sharp, P.A., \& Jacks, T. (2008) Targeted deletion reveals essential and overlapping functions of the miR-17 through 92 family of miRNA clusters. Cell. 132, 875-886. 
Villaret, A.; Galitzky, J.; Decaunes, P.; Estève, D.; Marques, M.A.; Sengenès, C.; Chiotasso, P.; Tchkonia, T.; Lafontan, M.; Kirkland, J.L., \& Bouloumié, A. (2010) Adipose tissue endothelial cells from obese human subjects: differences among depots in angiogenic, metabolic, and inflammatory gene expression and cellular senescence.

Villeneuve, L.M.; Kato, M.; Reddy, M.A.; Wang, M.; Lanting, L., \& Natarajan, R. (2010) Enhanced levels of microRNA-125b in vascular smooth muscle cells of diabetic $\mathrm{db} / \mathrm{db}$ mice lead to increased inflammatory gene expression by targeting the histone methyltransferase Suv39h1. Diabetes. 59, 2904-2915.

Villeneuve, L.M.; Reddy, M.A.; Lanting, L.L.; Wang, M.; Meng, L., \& Natarajan, R. (2008) Epigenetic histone H3 lysine 9 methylation in metabolic memory and inflammatory phenotype of vascular smooth muscle cells in diabetes. Proc. Natl. Acad. Sci. U.S.A. 105, 9047-9052.

Virtue, S. \& Vidal-Puig, A. (2010). Adipose tissue expandability, lipotoxicity and the Metabolic Syndrome--an allostatic perspective. Biochim. Biophys. Acta. 1801, 338-349.

Volkow, N.D.; Wang, G.J.; Telang, F.; Fowler, J.S.; Goldstein, R.Z.; Alia-Klein, N.; Logan, J.; Wong, C.; Thanos, P.K.; Ma, Y., \& Pradhan, K. (2009) Inverse association between BMI and prefrontal metabolic activity in healthy adults. Obesity (Silver Spring) 17, 1, 60-65.

Wakabayashi, K.; Okamura, M.; Tsutsumi, S.; Nishikawa, N.S.,; Tanaka, T.; Sakakibara, I.; Kitakami, J.; Ihara, S.; Hashimoto, Y.; Hamakubo, T.; Kodama, T.; Aburatani, H., \& Sakai,J. (2009) The peroxisome proliferator-activated receptor gamma/retinoid $X$ receptor alpha heterodimer targets the histone modification enzyme PR-Set7/Setd8 gene and regulates adipogenesis through a positive feedback loop. Mol. Cell Biol. 29, 3544-3555.

Wang, D., \& DuBois, R.N. (2008) Pro-inflammatory prostaglandins and progression of colorectal cancer. Cancer Lett., 267, 2,197-203.

Wang, Q.; Li, Y.C.; Wang, J.; Kong, J.; Qi, Y.; Quigg, R.J., \& Li, X. (2008) miR-17-92 cluster accelerates adipocyte differentiation by negatively regulating tumor-suppressor Rb2/p130. Proc. Natl. Acad. Sci. U.S.A. 105, 2889-2894.

Wang, Y. \& Beydoun, M.A. (2007) The obesity epidemic in the United States--gender, age, socioeconomic, racial/ethnic, and geographic characteristics: a systematic review and meta-regression analysis. Epidemiol. Rev. 29, 6-28.

Weisberg, S.P.; Hunter, D.; Huber, R.; Lemieux, J.; Slaymaker, S.; Vaddi, K.; Charo, I.; Leibel, R.L., \& Ferrante, A.W., Jr. (2006) CCR2 modulates inflammatory and metabolic effects of high-fat feeding. J. Clin. Invest. 116, 115-124.

Weisberg, S.P.; McCann, D.; Desai, M.; Rosenbaum, M.; Leibel, R.L., \& Ferrante, A.W., Jr. (2003) Obesity is associated with macrophage accumulation in adipose tissue. $J$. Clin. Invest. 112, 1796-1808.

White, C.L.; Pistell, P.J.; Purpera, M.N.; Gupta, S.; Fernandez-Kim, S.O.; Hise, T.L.; Keller, J.N.; Ingram, D.K.; Morrison, C.D., \& Bruce-Keller, A.J. (2009) Effects of high fat diet on Morris maze performance, oxidative stress, and inflammation in rats: contributions of maternal diet. Neurobiol. Dis., 35,1, 3-13. 
Wierda, R.J.; Geutskens, S.B.; Jukema, J.W.; Quax, P.H., \& van den Elsen, P.J. (2010) Epigenetics in atherosclerosis and inflammation. J. Cell Mol. Med. 14, 1225-1240.

Wolin, K.Y.; Carson, K., \& Colditz, G.A. (2010) Obesity and cancer. Oncologist. 15, 556-565.

Wu, Y.; Brodt, P.; Sun, H.; Mejia, W.; Novosyadlyy, R.; Nunez, N.; Chen,, X.; Mendoza, A.; Hong, S.H.; Khanna, C., \& Yakar, S. (2010) Insulin-like growth factor-I regulates the liver microenvironment in obese mice and promotes liver metastasis. Cancer Res., 70, 1, 57-67.

Xiao, C.; Srinivasan, L.; Calado, D.P.; Patterson, H.C.; Zhang, B.; Wang, J.; Henderson, J.M.; Kutok, J.L., \& Rajewsky, K. (2008) Lymphoproliferative disease and autoimmunity in mice with increased miR-17-92 expression in lymphocytes. Nat. Immunol. 9, 405414.

Xie H.; Lim B., \& Lodish HF. (2009) MicroRNAs induced during adipogenesis that accelerate fat cell development are downregulated in obesity. Diabetes 58, 5, 1050-1057.

Xu, H.; Barnes, G.T.; Yang, Q.; Tan, G.; Yang, D.; Chou, C.J.; Sole, J.; Nichols, A.; Ross, J.S.; Tartaglia, L.A., \& Chen, H. (2003) Chronic inflammation in fat plays a crucial role in the development of obesity-related insulin resistance. J. Clin. Invest. 112, 1821-1830.

Yaffe, K.; Kanaya, A.; Lindquist, K.; Simonsick, E.M.; Harris, T.; Shorr, R.I.; Tylavsky, F.A., \& Newman, A.B. (2004) The metabolic syndrome, inflammation, and risk of cognitive decline. JAMA, 292, 18, 2237-2242.

Yamamoto, Y.; Verma, U.N.; Prajapati, S.; Kwak, Y.T., \& Gaynor, R.B. (2003) Histone H3 phosphorylation by IKK-alpha is critical for cytokine-induced gene expression. Nature. 423, 655-659.

Yang, Z.; Kahn, B.B.; Shi, H., \& Xue, B.Z. (2010) Macrophage alpha1 AMP-activated protein kinase (alpha1AMPK) antagonizes fatty acid-induced inflammation through SIRT1. J. Biol. Chem., 285, 25, 19051-19059.

Yang, Z.; Bian, C.; Zhou, H.; Huang, S.; Wang, S.; Liao, L., \& Zhao, R.C. (2010) MicroRNA hsa-miR-138 inhibits adipogenic differentiation of human adipose tissue-derived mesenchymal stem cells through EID-1. Stem Cells Dev. 20, 259-67

Yoo, E.J.; Chung, J.J.; Choe, S.S.; Kim, K.H., \& Kim, J.B. (2006) Down-regulation of histone deacetylases stimulates adipocyte differentiation. J. Biol. Chem. 281, 6608-6615.

Zhang, C.Z.; Zhang, J.X.; Zhang, A.L.; Shi, Z.D.; Han, L.; Jia, Z.F.; Yang, W.D.; Wang, G.X.; Jiang, T.; You, Y.P.; Pu, P.Y.; Cheng, J.Q \& Kang, C.S. (2010) MiR-221 and miR-222 target PUMA to induce cell survival in glioblastoma. Mol. Cancer. 9, 1, 229-237.

Zhang, X.; Dong, F.; Ren, J.; Driscoll, M.J., \& Culver, B. (2005) High dietary fat induces NADPH oxidase-associated oxidative stress and inflammation in rat cerebral cortex. Exp. Neurol. 191, 2, 318-325.

Zhang, Y.; Daquinag, A.; Traktue,v D.O.; Amaya-Manzanares, F.; Simmons, P.J.; March, K.L.; Pasqualini, R.; Arap, W., \& Kolonin, M.G. (2009) White adipose tissue cells are recruited by experimental tumors and promote cancer progression in mouse models. Cancer Res. 69, 12, 5259-5266.

Zhang, Y.; Proenca, R.; Maffei, M.; Barone, M.; Leopold, L., \& Friedman, J.M. (1994) Positional cloning of the mouse obese gene and its human homologue. Nature. 372, 425-432. 
Zhu, N.; Zhang, D.; Chen, S.; Liu, X.; Lin, L.; Huang, X.; Guo, Z.; Liu, J.; Wang, Y.; Yuan, W., \& Qin, Y. (2011) Endothelial enriched microRNAs regulate angiotensin II-induced endothelial inflammation and migration. Atherosclerosis. 215, 286-93 


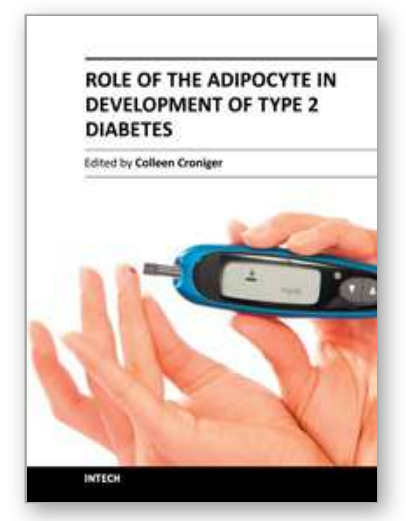

\author{
Role of the Adipocyte in Development of Type 2 Diabetes \\ Edited by Dr. Colleen Croniger
}

ISBN 978-953-307-598-3

Hard cover, 372 pages

Publisher InTech

Published online 22, September, 2011

Published in print edition September, 2011

Adipocytes are important in the body for maintaining proper energy balance by storing excess energy as triglycerides. However, efforts of the last decade have identified several molecules that are secreted from adipocytes, such as leptin, which are involved in signaling between tissues and organs. These adipokines are important in overall regulation of energy metabolism and can regulate body composition as well as glucose homeostasis. Excess lipid storage in tissues other than adipose can result in development of diabetes and nonalcoholic fatty liver disease (NAFLD). In this book we review the role of adipocytes in development of insulin resistance, type 2 diabetes and NAFLD. Because type 2 diabetes has been suggested to be a disease of inflammation we included several chapters on the mechanism of inflammation modulating organ injury. Finally, we conclude with a review on exercise and nutrient regulation for the treatment of type 2 diabetes and its co-morbidities.

\title{
How to reference
}

In order to correctly reference this scholarly work, feel free to copy and paste the following:

Perla Kaliman and Marcelina Párrizas (2011). Obesity and Systemic Inflammation: Insights into Epigenetic Mechanisms, Role of the Adipocyte in Development of Type 2 Diabetes, Dr. Colleen Croniger (Ed.), ISBN: 978953-307-598-3, InTech, Available from: http://www.intechopen.com/books/role-of-the-adipocyte-indevelopment-of-type-2-diabetes/obesity-and-systemic-inflammation-insights-into-epigenetic-mechanisms

\section{INTECH}

open science | open minds

\section{InTech Europe}

University Campus STeP Ri

Slavka Krautzeka 83/A

51000 Rijeka, Croatia

Phone: +385 (51) 770447

Fax: +385 (51) 686166

www.intechopen.com

\section{InTech China}

Unit 405, Office Block, Hotel Equatorial Shanghai

No.65, Yan An Road (West), Shanghai, 200040, China 中国上海市延安西路65号上海国际贵都大饭店办公楼 405 单元 Phone: +86-21-62489820

Fax: $+86-21-62489821$ 
(C) 2011 The Author(s). Licensee IntechOpen. This chapter is distributed under the terms of the Creative Commons Attribution-NonCommercialShareAlike-3.0 License, which permits use, distribution and reproduction for non-commercial purposes, provided the original is properly cited and derivative works building on this content are distributed under the same license. 